\title{
THYROID STORM AFTER CHEST TRAUMA
}

\section{AUTHORS}

Tatjana Novaković1, Bogdan Dejanović ${ }^{2}$ Zdravko Vitošević ${ }^{1}$, Nenad Milošević ${ }^{\text {, }}$ Jovana Milošević ${ }^{1}$, Ljiljana Jovićević ${ }^{4}$, Emilija Novaković ${ }^{3}$, Miloš V Mirković ${ }^{1}$, Zlatica Mirković

${ }^{1}$ Department of Internal Medicine, Clinical Center of Pristina, Medical Faculty of Pristina, University of Kosovska Mitrovica

${ }^{2}$ Institute of Rheumatology, Belgrade, Serbia

${ }^{3}$ Medical faculty Kosovska Mitrovica

${ }^{4}$ Health Centre of Bar, Montenegro

\section{SUMMARY}

Thyroid storm is an acute and severe complication of thyrotoxicosis. It is characterized by high fever, sweating, tachycardia, and often heart failure too. The objectives of the paper is to present the case of a patient with thyroid storm developed after the trauma of the chest at previously apparently healthy individuals, diagnosed on the basis of clinical preview and based on the diagnostic criteria according to Burch and Wartofsky. The most common complication is Mb. Graves - Basedow, but often associated with multi-nodose goiter. Thyroid storm is the most severe form of thyrotoxicosis with a mortality rate of 8 to $25 \%$. Case report. We present an interesting case from our practice: thyroid storm caused after chest trauma in apparently healthy people, but with unrecognized hyperthyroidism and thyroid gland nodule. Conclusion. The objectives of this presentation were to raise awareness of the association between signs and symptoms of thyroid storm that dominate the clinical picture and complicate the initial presentation and the evolution of the situation caused by trauma. The treatment of hyperthyroidism resulted in conversion in sinus rhythm, withdrawal of symptoms and signs heart failure, and normalization of artery pressure.

Key words: thyroid storm, hyperthyroidism, chest trauma

\section{SRPSKI}

\section{TIROIDNA KRIZA POSLE TRAUME GRUDNOG KOŠA}

Tatjana Novaković1, Bogdan Dejanović2, Zdravko Vitošević1, Nenad Milošević1, Jovana Milošević 1, Ljiljana Jovićević4, Emilija Novaković3, Miloš V Mirković1, Zlatica Mirković1

${ }^{1}$ IKlinički centar u Prištini, Medicinski fakultet u Prištini, Univerzitet u Kosovskoj Mitrovici

${ }^{2}$ Institut za reumatologiju, Beograd, Srbija

${ }^{3}$ Medicinski fakultet u Prištini, Univerzitet u Kosovskoj Mitrovici

${ }^{4}$ Dom zdravlja Bar, Crna Gora

\section{SAŽETAK}

Tiroidna kriza je akutna i teška komplikacija tirotoksikoze. Karakteriše je visoka temperatura, znojenje, tahikardija a često $i$ srčana insuficijencija. Cilj rada je da se prikaže slučaj pacijenta sa tiroidnom krizom razvijenom nakon traume grudnog koša, kod prethodno naizgled zdrave osobe, dijagnostikovana na osnovu kliničkog pregleda i zasnovana na dijagnostičkim kriterijumima prema Burch - a i Vartofsk - og. Najčešće je kompikacija Grejs - Bazedovljeve bolesti, često je povezana sa multi-nodoznom strumom. Tiroidna kriza je najteži oblik tirotoksikoze sa stopom smrtnosti od 8 do $25 \%$. Prikaz slučaja. U radu je prikazan interesantan slučaj iz kliničke prakse, pacijentkinja sa tiroidnom krizom, naizgled zdrava ali sa neprepoznatim hipertireoidizmom i čvorom u štitastoj žlezdi. Zaključak. Cilj ovog prikaza slučaja bio je ukazati na značaj prepoznavanja hipertireoze povezanosti znakova i simptoma tiroidne krize, koji komplikuju početnu prezentaciju i tok situacije izazvane traumom. Lečenje hipertireoze rezultiralo je konverzijom u sinusni ritam, povlačenje simptoma i znakova insuficijencije srca i normalizaciju arterijskog pritiska.

Ključne reči: tiroidna kriza, hipertireoza, trauma grudnog koša 


\section{INTRODUCTION}

The extreme manifestation of thyrotoxicosis is thyroid storm, which manifests as an acute, severe, life-threatening hypermetabolic state caused either by excessive release of thyroid hormones, causing adrenergic hyperactivity, or altered peripheral response to thyroid hormone following the presence of one or more precipitants [1].

The incidence of thyroid storm in the general population is not known [2]. Thyroid storm is a rare and potentially fatal complication of hyperthyroidism characterized by multisystem involvement and mortality rates in the range of 8 $25 \%$ in modern series, but it has been reported to be as high as $75 \%$ in hospitalized populations. Underlying precipitating illness may contribute to high mortality $[3,4,5]$. Multiple organ failure was reported to be the most common cause of death in thyroid storm, followed by congestive heart failure, respiratory failure, arrhythmia, disseminated intravascular coagulation, gastrointestinal perforation, hypoxic brain syndrome, and sepsis [3].

The presentation does not depend on serum thyroid hormones concentrations, which are similar to compensated thyrotoxicosis [3]. Thyroid storm is almost always preceded by some precipitating factor. An apparent trigger can be identified in up to $70 \%$ of cases: usually unreliable use or discontinuation of anti-thyroid drugs, followed by infection. Other risk factors include acute illness, thyroid or nonthyroid surgery (now less common, as a result of appropriate preoperative preparation), trauma, stress, and pregnancy [6]. History of recent traumas in the neck area should always be searched for in patients without history of thyroid disease $[7,8,9]$. Occasionally, the clinical picture of apathetic thyrotoxicosis occurs, in particular in older patients, especially women $[10,11]$. There are no clear criteria that would define the point at which thyrotoxicosis becomes thyroid storm. Basic fact is that a dramatic increase of the free fraction of thyroid hormone is a common denominator of precipitating factors in thyroid storm [12].

The diagnosis of thyroid storm is based on the combination of clinical signs and laboratory findings. Thyroid storm is a clinical diagnosis for patients with preexisting hyperthyroidism. To make the diagnosis, Burch and Wartofsky [2] proposed a scoring system modified by Akamizu and colleagues [3]. Diagnostic criteria for thyroid storm in patients with severe thyrotoxicosis were first proposed in 1993 and subsequently widely adapted as the Burch-Wartofsky Point Scale (BWPS) for thyroid storm. These criteria include hyperpyrexia, tachycardia, arrhythmias, congestive heart failure, agitation, delirium, psychosis, stupor, and coma, as well as nausea, vomiting, diarrhea, hepatic failure, and the presence of an identified precipitant .[2]. Points in the BWPS system are based on the severity of individual manifestations, with a point total of 45 consistent with thyroid storm, 25-44 points classified as impending thyroid storm, and $<25$ points making thyroid storm unlikely. However, Japanese scientists have proposed a different scoring system, in which also our patients meet the criteria for the diagnosis of thyroid storm. According to this method of diagnosis, an absolute criterion is elevated levels of free free thyroxine (freeT4) and/or free triiodothyronine (freeT3) with normal serum thyroid-stimulating hormone (TSH) or suppressed, and the presence of certain symptoms from the central nervous system, cardiovascular system, and the gastrointestinal tract [3].

Thyroid storm, an endocrine emergency, remains a diagnostic and therapeutic challenge. A multidisciplinary trea- tment approach should be used. Goals of treatment are lowering of thyroid hormone synthesis and secretion, reduction of circulating thyroid hormones, control of the peripheral effects of thyroid hormone, resolution of systemic manifestation, and identifying and treating precipitating factors $[1,2,3,12,14]$. Definitive therapy with thyroidectomy or radioactive iodine is suggested after the patient becomes euthyroid $[13,14]$.

\section{CASE PRESENTATION}

A-70-year women was admitted to our hospital because of weakness, fatigue, profuse sweating, rapid heartbeat, choking, swelling of the shanks higher body temperature. Two weeks prior to admission she had development fever, diarrhea and heart failure. A diagnosis of cardiomyopathy decompensate was made at a local clinic, and she was treated with symptomatic therapy, no improvement in her symptoms was seen. Personal history, two weeks before admission in the local clinic she had an injury of the chest, she had hysterectomy 25 years ago, non- smoker, drinks alcohol occasionally. The patient had no family history of chronic diseases. Glasgow comma scale for consciousness, 8, (E2V2M4). On examination the patient was pale, respiratory rate was $25 / \mathrm{min}$ and body temperature $38,5^{\circ} \mathrm{C}$, oxygen saturation, $85 \%$. The jugular veins were distended. There was a moderate and diffuse enlargement of the thyroid gland with palpable nodules. Auscultation of the lungs indicates late inspirium audible crackles in the bases. Physical examination revealed tachycardia with irregular heart rhythm, heart rate was 130 beats per min.; systolic murmur in the precordial punctum max., over the ictus; blood pressure was $130 / 80 \mathrm{~mm}$ $\mathrm{Hg}$. Abdominal distension, and bilateral leg edema were also noticed. An electrocardiography revealed atrial fibrillation with rapid ventricular response, heart rate was about $130 /$ min. Chest roentgenogram showed skeletal system in the visible osteoporotic, cardiomegaly and aortic button sclerotic, left frenico-costal sinus, middle and lower lung shaded, hiluses are convex. The patient underwent without contrast chest computed tomography (CT) and in left lobe of the thyroid gland enlarged, with well-defined nodule measuring $25 \times 35 \mathrm{~mm}$, right lobe was normal. Ultrasound of the thyroid gland: the left lobe enlarged in general, it can visualize the inhomogeneus nodule measuring $25 \times 35 \mathrm{~mm}$, no regional lymphadenopathy [Figure 1.]. Thyroid function test showed severe thyrotoxicosis with a free T4 $53 \mathrm{pmol} / \mathrm{L}$, normal range, (8.4-23.2 pmol/L) and free T3 $20 \mathrm{pmol} / \mathrm{L}$, (normal range, 3.1-6.5 pmol/L), as well as a low TSH level of $<0.05 \mu \mathrm{U} / \mathrm{ml}$, (reference range 0.25-5.0 $\mu \mathrm{U} / \mathrm{ml}$ ). The antithyroglobulin antibody level was in the range referent values (normal range 0-80 $\mathrm{IU} / \mathrm{mL}$ ), and so was the anti-thyroperoxidase antibody level (normal range $0-130 \mathrm{U} / \mathrm{mL}$ ). Increased levels of glycemia $(9.8 \mathrm{~mol} / \mathrm{L}$, normal range 4.2-6.4 $\mathrm{mmol} / \mathrm{L})$, total holesterol $(3.5 \mathrm{mmol} / \mathrm{L}$, normal range 3.9 $6.7 \mathrm{mmol} / \mathrm{L}$ ), alkaline phosphatase (287 IU/L, normal 30-120 IU/L) and uric acid (366 $\mu \mathrm{mol} / \mathrm{L}$, normal 154-357 $\mu \mathrm{mol} / \mathrm{L})$ were also detected. Sedimentation rate was increased ( 50 , normal range $0-20 \mathrm{~mm} / \mathrm{hr}$ for women), with the increased white blood cells count $\left(14.6 \times 10^{9} / \mathrm{L}\right.$, normal range $3.5-10.5$ billion cells/L), electrolyte imbalance is present, $\mathrm{K}(2.9$ $\mathrm{mmol} / \mathrm{L}$, normal range $3.6-5.5 \mathrm{mmol} / \mathrm{L}) \mathrm{Na}(116 \mathrm{mmol} / \mathrm{L}$, normal range $135-155 \mathrm{mmol} / \mathrm{L}), \mathrm{Ca}(1.21 \mathrm{mmol} / \mathrm{L}$, normal range 2.2-2.6 mmol/L) antinuclear antibodies and rheumatoid factor were normal. The diagnosis of Struma nodosa toxica was established on the basis of different clinical findings: 
thyroid hormones and clinical signs hyperthyroidism and nodular goiter. The patient's condition suggested thyroid storm triggered by chest trauma in apparently healthy person, considering her clinical signs and symptoms with the very short period of treatment with propiltiouracil (PTU). Based on the Burch and Wartofsky's score [2] which is a widely used global scale for evaluating the severity of thyrotoxicosis, the patient 's condition was diagnosed as thyroid storm, thyrotoxicosis with mild agitation (10 points), moderate heart failure (10 points), tachycardia of 130 beats/min ( 25 points), and atrial fibrillation (10 points), a fever over 38,3 (15 points), diarrhea (10 points), for a total score of 80 (61 point or higher is definitive of a thyroid storm). We started treatment with steroids (hydrocortisone $100 \mathrm{mg}$ at 8 hours), propranolol (40 mg each 6 hours), and PTU $200 \mathrm{mg}$ in 6 hours and furosemide. In the current case, the absence of a suitable iodine preparation forced us to use PTU instead, and we followed the hepatic panel carefully. The severe watery diarrhea persisted, and the laboratory data revealed hypokalemia $(2.9 \mathrm{mmol} / \mathrm{L})$. She was hydride by physiological solutions and electrolyte management, corrected by hypokalemia. Lowmolecular-weight heparin was added to therapy because of atrial fibrillation. Insulin was used to control her glycemia. Her gastrointestinal symptoms treated with a proton-pump inhibitor. Three days after the intensive treatment, medical status improved gradually, in the further treatment the patient has not been febrile, state of mind has been improved, she began to communicate, the ECG leads to deceleration of heart action, and later the establishment of sinus rhythm, the findings in the lungs and edema withdrew. She was discharged from our hospital in euthyroid state with recommendation for surgical treatment.

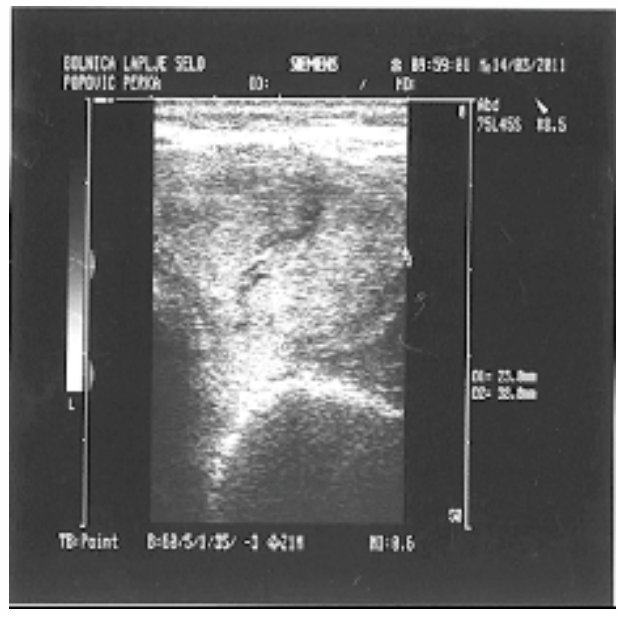

Figure 1. The ultrasound of thyroid gland shows a well-defined inhomogeneous nodule measuring $25 \times 35 \mathrm{~mm}$ in the left

\section{DISCUSSION}

This review was interesting because it was the patient who had the trauma of the chest without previously health problems. She wasn't aware of a nodule in the thyroid gland, never treated for hyperthyroidism. Usually, thyroid hormone levels correlate with clinical presentation, but some the patients have got masked or apathetic hyperthyroidism $[10,11]$. In elderly persons manifestations of hyperthyroidism may be latent and in some cases limited just to the cardiovascular system, we believe that it is likely to be the case with our patient. Chest trauma was a precipitating factor which is produced in latent hyperthyroidism manifest of thyroid storm. The diagnosis of thyroid storm in the our patient has been based on the above criteria [1,2,3]. Identification of these patients is very important for recognition and timely introduction of therapy, which dramatically improves the condition $[1,2,3,14]$.

Thyroid storm is a rare status. After analyzing data from the literature available to us, we have obtained the trauma as a direct cause of the development of thyroid storm described only in a few cases to date. Girish [15] et al. have presented a patient, aged 40 years with multiple injuries after a car accident. Although polytraumatized, he was hemodynamically stable state of mind has been assessed with the Glasgow Scala on 15, within a few hours he became confused, stupor, body temperature was increased, pulse speed up to $140 / \mathrm{min}$. From hetero-anamnesis, obtained from the fact that last year knew about the enlarged thyroid without symptoms. Three days after diagnosis and applied primarily adequate anti-thyroid therapy, the condition is dramatically improved. In our patient, the change of pulse was present from the beginning, accompanied by atrial fibrillation, also a state of mind has been changed three days after the admission, after setting the suspicion of thyroid crisis and treatment, condition of patients improved dramatically.

In the paper of Wilkinson [16] it has been also described of patient who after a car accident developed thyroid storm, which has significantly complicated clinic appearance and prolonged treatment. In addition to the general trauma of the above cases, the local blunt, penetrating trauma of the thyroid gland can accelerate the development of thyroid storm. This study demonstrates that thyroid gland injury due to blunt neck trauma, although uncommon, may result in potentially life-threatening thyroid storm due to rupture of acini and liberation of thyroid hormones into the bloodstream. This may occur in patients without known hyperthyroidism [8].

This case demonstrated the importance of a neck examination with palpation of the thyroid gland. Early recognition with a full clinical history and physical examination and aggressive treatment are fundamental in limiting the morbidity and mortality associated with this endocrine emergency.

\section{CONCLUSION}

The objectives of this presentation were to raise awareness of the association between signs and symptoms of thyroid storm that dominate the clinical picture and complicate the initial presentation and the evolution of the situation caused by trauma. For this state it should be thaught especially in terms of hyperthyroidism and diagnosis should be set on the basis of suspicious and non-specific clinical signs before thyroid gland being tested.

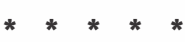

\section{Declaration of interest}

The authors declare that there is no conflict of interest that could be perceived as prejudicing the impartiality of the research reported.

\section{Patient consent}

Written informed consent was obtained from the patient for publication of the case report and accompanying images. 
1. Ross DS, Burch HB, Cooper DS, Greenlee MC, Laurberg P, Maia AL et al. American Thyroid Association Guidelines for Diagnosis and Management of Hyperthyroidism and Other Causes of Thyrotoxicosis. Thyroid. 2016 Oct; 26(10):1343-1421.

2. Wartofsky L. Thyrotoxic storm. In: Braverman L, Utiger R (eds) Werner \& Ingbar's the Thyroid, 9th edition. Williams \& Wilkins, Philadelphia, 2005; pp. 651-657.

3. Akamizu T, Satoh T, Isozaki O, Suzuki A, Wakino S, Iburi T et al. Diagnostic criteria, clinical features, and incidence of thyroid storm based on nationwide surveys. Thyroid. 2012; 22:661-679.

4. Klein I, Danzi S. Thyroid disease and the heart. Circulation, 2007, 116: 1725-1735.

5. Angell TE, Lechner MG, Nguyen CT, Salvato VL, Nicoloff JT, LoPresti JS. Clinical features and hospital outcomes in thyroid storm: a retrospective cohort study. J Clin Endocrinol Metab. 2015 Feb;100 (2):451-9.

6. Chen JJ, Ladenson PW. Discordant hypothyroxinemia and hypertriiodothyroninemia in treated patients with hyperthyroid Graves' disease. J Clin Endocrinol Metab 1986, 63:102-106.

7. Arunabh A., Sardu AK, Kamakar MG. Changes in thyroid hormones in surgical trauma. Journal of Post Graduate Medicine 1992; 38: 117-8.

8. Delikoukos S, Mantzos F. Thyroid storm induced by blunt thyroid gland trauma. Am Surg.2007, 73:1247-9.

9. Hagiwara A, Murata A, Matsuda T, Sakaki S, Shimazaki S. Thyroid storm after blunt thyroid injury: a case report. J Trauma 2007, 63:E85-7.

10. Thomas FB, Mazzaferri EL, Skillman TG: Apathetic thyrotoxicosis: a distinctive clinical and laboratory entity. Ann Intern Med 1970,72: 679

11. Ghobrial MW, Ruby EB. Coma and thyroid storm in apathetic thyrotoxicosis. South Med J 2002, 95:552-4.

12. Sarlis JN, Gourgiotis. Thyroid Emergencies. Rev End Metab Dis 2003; 4:129-136.

13. De Leo S, Lee SY, Braverman LE. Hyperthyroidism Lancet. 2016, 27;388(10047):906-18.

14. Satoh T, Isozaki O, Suzuki A, Wakino S, Iburi T, Tsuboi K, Kanamoto N, Otani H, Furukawa Y, Teramukai S, Akamizu T. Guidelines for the management of thyroid storm from The Japan Thyroid Association and Japan Endocrine Society (First edition).Endocr J. 2016 Dec 30;63(12):1025-1064.

15. Sabnis GR, Karnik ND, Chavan SA, Korivi DS, Pati MV.Trauma Precipitating Thyroid Storm, Journal of Association of Phisicans of India, 2011 Vol. 59, 117-118.

16. Wilkinson JN. Thyroid storm in a polytrauma patient, Anaesthesia. 2008; 63(9):1001-5.

“Rad posvećujemo našem dragom kolegi dr Bogdanu Dejanoviću koji je izgubio bitku sa Korona virusom, a bio je deo tima koji je uradio ovaj rad" 